\title{
Advance Notice
}

\section{of forthcoming meetings}

Special Meetings of the Geology and Metal Mining Divisions of the Canadian Institute of Mining \& Metallurgy 1967

September 18-22:

Course on Statistics and Computer Operations Montreal, Quebec

September 25-27:

Conference on Ore Reserve Estimation and Grade Control

L'Estérel, Quebec

September 28 - October 6 :

Geological Field Trip to Northwestern Quebec and Northern Ontario

The detailed program of these activities will be mailed to Members of these Divisions in early July. Because of limited accomodations during this period of EXPO '67, all participants will be required to register in advance. Requests will be filled on a first-come, first-served basis. Plan your activities NOW in order not to miss these important meetings.

For information write to:

Geology \& Metal Mining Divisions,

L'Estérel Conference,

P.O. Box 1084,

Place d'Armes,

Montreal 1, Que.

\section{Corrigendum Notice}

Minetalium Deposita, 1, 317-321 (1967) AMstuTz G. C., tion of Framboidal Pyrite in Shale". Figure 1. The L. G. Love, W. C. PARK and E. H. Schot: "Orientafigure 1 must be turned by $180^{\circ}$. It stands upside-down. 